\title{
AN UNUSUAL ARTHROPOD ASSEMBLAGE WITHIN A NEW SILURIAN SOFT-BODIED FAUNA FROM SOUTHERN BRUCE PENINSULA, ONTARIO, CANADA
}

\author{
TETREAULT, Denis K., Department of Earth Sciences, University of Western \\ Ontario, London, Ontario, Canada N6A 5B7
}

In most Paleozoic near-shore benthic faunas, arthropods are normally represented by the heavily sclerotized members of the Trilobita, while other arthropod groups are poorly, or not at all represented. Within a new Silurian (lower Ludlow) fauna from the Eramosa Member of the Guelph Formation in southern Bruce Peninsula this pattern has been reversed due to the phosphatization of non-calcified organisms. The fauna occurs within very thinly laminated, light to very dark brown, petroliferous dolostones.

Trilobites are very rare in the fauna but include Dalmanites, Acanthopyge, a calymenid, and an encrinurid. Though they are often articulated, with hypostomes intact, the exoskeletons are in most cases completely decalcified and the organisms are represented only by very faint impressions. Other elements of the fauna originally composed of calcium carbonate, such as ophiuroids, echinoids, brachiopods, cephalopods, gastropods and bivalves, are also preserved in much the same manner.

In contrast, lightly sclerotized arthropods and other soft-bodied organisms (including several worms) are much better preserved by the replacement of tissue by calcium phospate, sometimes preserving the gut tract as well. Among them are several problematic arthropods, including one with a pair of large grasping anterior appendages.

The most common arthropods in the fauna are the phyllocarids, Ceratiocaris being the dominant genus, and they show varying degrees of preservation. Most of the articulated individuals represent carcasses with intact jaw elements. Many specimens resemble the type of preservation commonly seen in phyllocarids at other localities, with only the abdomenal and caudal segments and carapace present. However, within the phosphatized fauna, preservation of the thoracic segments is common, sometimes with longitudinal muscle fibers and pleopod elements visible. Long, narrow abdomenal telopods are also preserved in some specimens. 